\title{
PRAGMATICS FUNCTIONS OF PERLOCUTIONARY ACT IN LEVELED READING BOOK
}

\author{
Juliantina \\ Dosen STKIP Budidaya Binjai \\ juliantinasebayang@gmail.com
}

\begin{abstract}
Perlocutionary act is the result of the effect of an utterance. Perlocutionary act brings the hearer to learn something, persuade, deceive, encourage, irritate, frighten, amuse, get the hearer to do something, inspire, impress, distract, get the hearer to think about, relieve tension, embarrass, attract attention, bored. Perlocutionary act is a speech act spoken by a speaker to influence the interlocutors and can be found in the communication process. One form of communication process can be found in conversations between the characters in story from children's reading book. Perlocutionary act is uttered with different pragmatic functions according to the context of the speech. The objectives of this journal are to describe the functions of perlocutionary act in levelled reading book. The journal approach used pragmatics and qualitative approach.
\end{abstract}

Keyword : perlocutionary act, pragmatic function, levelled reading book

\section{INTRODUCTION}

Language is a highly elaborated signalling system. Language has been examined by linguists and philosophers for several millennia. Language is composed of separate sounds, words, sentences and other utterance units. The fact that we hear speech as a sequence of individual sounds, words, and sentences is actually an incredible accomplishment (and all the more incredible for how instantaneously and unconsciously we do it). Acoustically sounds and words blend into each other. (If you have tried to learn a second language as an adult, you know how hard it can be to separate words spoken at a normal conversational pace.)

Remarkably, babies only a few weeks old are able to distinguish even closely related sounds in the language of their home from each other and to distinguish the sounds that belong to the language they are learning from the sounds in other languages at a very early age.

Furthermore, children in the first year or two of life learn to pick out words from the stream of speech with no instruction. All languages are organized into constituents, allowing more complex units to enter structures where simpler ones are also possible. Language is a distinctive attribute of the human species.

Speech situation and speech act occur in the communication process. The speech situation is a situation that causes speech (Rustono, 2017). A speech situation consists of several components. They are speaker and interlocutors, speech context, speech objectives, speech act as a form of action or activity, and utterance as a product of verbal action.

The speech act process is determined by the context that accompanies the utterance (Umaroh \& Kurniawati, 2017). Speech act, which is an analysis unit in pragmatic field, is 
an activity of making an utterance in certain conditions that represent an action.

Pragmatics is a subfield of linguistics and semiotics that studies the ways in which context contributes to meaning. Pragmatics encompasses speech act theory, conversational implicature, talk in interaction and other approaches to language behaviour in philosophy, sociology, linguistics and anthropology.

Pragmatics studies how the transmission of meaning depends not only on structural and linguistic knowledge (grammar, lexicon, etc.) of the speaker and listener but also on the context of the utterance, any pre - existing knowledge about those involved, the inferred intent of the speaker, and other factors.

Pragmatics explains how language users are able to overcome apparent ambiguity since meaning relies on the manner, place, time, etc. of an utterance. The ability to understand another speaker's intended meaning is called pragmatic competence.

Pragmatics is the study of human communication: the choices speakers make to express their intended meaning and the kinds of inferences that hearers draw from an utterance in the context of its use. Pragmatics refers to the way we convey meaning through communication. This meaning includes verbal and non - verbal elements and varies depending on the context, the relationship between people talking, and many other social factors.

Language also plays an important role in the world literature because during the development of literary world there are many other languages that can be learned and used as a useful knowledge (Yuliarti, Rustono, \& Nuryatin, 2015).

The vocabulary, language structure, and phrases used in children's literature are simple (Nurgiyantoro, 2013). One form of children's literature is children's reading books. The example of children's reading books that have been widely distributed is leveled reading books published by Level noted F\&P Level is unvallable.

The leveled reading book is disseminated in 2016 to 12,000 selected Elementary Schools in 9 provinces in Indonesia by USAID (USAID, 2017). This book through a combination of text, pictures, and book related discussions and exercises the books promote increased comprehension, expansion of vocabulary, and skill development. The books also promote greater awareness of the importance of reading among students, parents, teachers, school administrators, and government officials.

This journal is pragmatic function of perlocutionary speech act and its dominance in leveled reading book. Perlocutionary speech act is a speech act which is uttered in order to make the interlocutors affected by the content of the utterance.

Perlocutionary act is the result of the effect of an utterance. Perlocutionary act brings the hearer to learn something, persuade, deceive, encourage, irritate, frighten, amuse, get the hearer to do something, inspire, impress, distract, get the hearer to think about, relieve tension, embarrass, attract attention, bored.

\section{METHODS}

The theoretical approach of this journal was pragmatic approach which was used to discover the meaning of an utterance. The 
methodological approach used in this journal was qualitative approach because the data in this journal were not in form of numbers yet, the story fragments in leveled reading book which are suspected containing perlocutionary act.

This journal data were obtained from leveled reading book. This book is still classified as newly used in some elementary schools, so there has not been much research done related to leveled reading book. In addition, the book is used by many elementary schools scattered in various regions of Indonesia and contains good moral values for children. The data collection method used in this study was observation method with advanced technique of writing technique.

\section{DISCUSSION \\ 1. Definition of Pragmatics}

Pragmatics is a subfield of linguistics and semiotics that studies the ways in which context contributes to meaning. Pragmatics encompasses speech act theory, conversational implicature, talk in interaction and other approaches to language behaviour in philosophy, sociology, linguistics and anthropology.

Pragmatics studies how the transmission of meaning depends not only on structural and linguistic knowledge (grammar, lexicon, etc.) of the speaker and listener but also on the context of the utterance, any pre - existing knowledge about those involved, the inferred intent of the speaker, and other factors.

Pragmatics explains how language users are able to overcome apparent ambiguity since meaning relies on the manner, place, time, etc. of an utterance. The ability to understand another speaker's intended meaning is called pragmatic competence.

Pragmatics is the study of human communication: the choices speakers make to express their intended meaning and the kinds of inferences that hearers draw from an utterance in the context of its use. Pragmatics refers to the way we convey meaning through communication. This meaning includes verbal and non - verbal elements and varies depending on the context, the relationship between people talking, and many other social factors.

\section{Pragmatic Function}

Pragmatic function is the meaning a speaker wishes to convey to the person they are speaking to (the addressee). Now usually the meaning of the individual words will give the addressee the meaning that the speaker wants to give, but NOT always.

\section{Examples of Pragmatics}

- He hasn't taken a shower.

- He was so hungry he could eat the whole table.

- $\quad$ Please shut the door.

- The book is lying on that table.

- Do you want go out to eat dinner with me?

- Would you like to see a movie?

- It is too long of a trip to go up the stairs.

- $\quad$ I get tired every time I walk up there.

- $\quad$ Could the door be any further away?

- $\quad$ The chicken is ready to eat.

\section{Definition of Perlocutionary}

Perlocutionary speech act is a speech act which is uttered in order to make the interlocutors affected by the content of the utterance. Perlocutionary act is the result of the effect of an utterance. Perlocutionary act brings the 
hearer to learn something, persuade, deceive, encourage, irritate, frighten, amuse, get the hearer to do something, inspire, impress, distract, get the hearer to think about, relieve tension, embarrass, attract attention, bore.

The aim of perlocutionary act is to change feelings, thoughts, or actions. Perlocutionary act is a speech act spoken by a speaker to influence the interlocutors and can be found in the communication process.

\section{Examples of Perlocutionary act:}

- I was born a Filipino, I will live a Filipino, I will die a Filipino! ( inspiring )

- It is the bleak job situation that forces Filipinos to find jobs overseas. ( persuading )

- $\quad$ Texting while driving kills - you, your loved ones, other people! ( deterring )

\section{Definition of Reading}

Reading is a number of interactive processes between the reader and the text, in which readers use their knowledge to build, to create, and to construct meaning. Reading is a constructive process, reading must be fluent, reading must be strategic, reading requires motivation, and reading is a continuously developing skill.

\section{Definition of Leveled Reading Book}

The leveled reading book is disseminated in 2016 to 12,000 selected Elementary Schools in 9 provinces in Indonesia by USAID (USAID, 2017). This book through a combination of text, pictures, and book related discussions and exercises the books promote increased comprehension, expansion of vocabulary, and skill development. The books also promote greater awareness of the importance of reading among students, parents, teachers, school administrators, and government officials.

\section{RESULTS}

Based on the result of the journal, it can be proposed that perlocutionary can improve children pragmatics. When perlocutionary were implemented in teaching pragmatics it could improve the children pronunciation, vocabulary, and content. Besides, the using of perlocutionary can improve classroom situation of pragmatics class better.

This study emphasizes the pragmatic function of perlocutionary act based on existing utterance intentions unlike research conducted. In addition, this study does not merely examine the pragmatic function of perlocutionary act in the leveled reading book but also examines the dominance function.

\section{CONCLUSION \& SUGGESTION 1. Conclusion}

Based on the results of this study, it can be concluded that of pragmatic is Pragmatics is a subfield of linguistics and semiotics that studies the ways in which context contributes to meaning. And Pragmatics explains how language users are able to overcome apparent ambiguity since meaning relies on the manner, place, time, etc. of an utterance. While, Perlocutionary speech act is a speech act which is uttered in order to make the interlocutors affected by the content of the utterance. The aim of perlocutionary act is to change feelings, thoughts, or actions.

\section{Suggestion}

The use of perlocutionary act in pragmatic lessons can help children in pronounciation, vocabulary, and content. And the use of perlocutionary can also make the classroom situation even better. 


\section{REFERENCES}

Team Teaching. Pragmatics: STKIP BUDIDAYA BINJAI.

Team Teaching. Introduction to Linguistics. STKIP BUDIDAYA BINJAI.

Keith Allan \& Kasia M. Jaszczolt. 2012. The Cambridge Handbook of Pragmatics. Cambridge: University Press.

Patrick Griffiths. 2006. An Introduction to English Semantics \& Pragmatics. Edinburgh: University Press.
Ralph W. Fasold \& Jeff Connor - Linton. 2006. An introduction to language and linguistics. Cambridge: University Press.

Ingrid Elisabeth Nufsfjord Kvitnes. 2013. Subtitles in the second language classroom. Norwegian University.

Pearson. 2013. Reading Course Book. Canada.

Heos, Bridget. Leveled Reading Book.

Bryce becker, 2016. What is Reading? University of California.

Swiny Andina. 2016. Leveled Reading Book. USAID Indonesia. 